\title{
5
}

\section{Woman of Maxims: George Eliot and the Realist Imperative}

Much quotation of any sort, even in English, is bad.

- Sir Hugo, in George Eliot's Daniel Deronda

A quotation of ten makes a fine summit to a climax, especially when it comes from some elder author... But I hate a style speckled with quotations.

-George Eliot, Letter to Alexander Main

Good phrases are surely, and ever were, very commendable.-Justice Shallow

—George Eliot, Middlemarch

Fielding lived when the days were longer (for time, like money, is measured by our needs)... We belated historians must not linger af ter his example; ... I at least have so much to do in unraveling certain human lots and seeing how they were woven and interwoven that all the light I can command must be concentrated on this particular web, and not dispersed over that tempting range of relevancies called the universe.

-George Eliot, Middlemarch

All people of broad, strong sense have an instinctive repugnance to the men of maxims because such people easily discern that the mysterious complexity of our life is not to be embraced by maxims and that to lace ourselves up in formulas of that sort is to repress all the divine promptings and inspirations that spring from growing insight and sympathy.

—George Eliot, Mill on the Floss 
If we judge from the content of these passages, it would seem that George Eliot considered quotation and generalization at worst odious and irresponsible, at best the product of an age when "unraveling human lots" was easier. Mary Jacobus has argued that not only Maggie Tulliver but her creator professed distrust for maxims and the men who made them. In a similar spirit, Susan Gubar and Sandra Gilbert describe Middlemarch's narrator as "highly provisional and tentative." Carol Gilligan even makes the narrator of The Mill on the Floss her paradigm of "feminine" moral consciousness, and the "master-key that will fit all cases" her trope for a disfavored "male" hierarchy of right. ' And where, indeed, could one find a more Gilliganesque position than The Mill on the Floss's assertion that "moral judgments must remain false and hollow unless they are checked and enlightened by a perpetual reference to the special circumstances that mark the individual lot"? ${ }^{2}$ Such criticism has constructed a George Eliot who sets herself against the very concept of authoritative voice.

Ironically, however, Eliot's professed distrust of quotation and maxim stands in Archimedean tension with her formal practices: if Eliot is suggesting that the authority of such forms is but a fiction, she does so through fiction's arguably most authoritative, "nonfictional" structures - precisely maxims and quotations, the conventional forms for authorial wisdom, detachable from the story proper and able to engage "that tempting range of relevancies called the universe." Eliot's insistence that imaginative discourse could perform an "office for the mind" that no philosophical pronouncement could achieve, her strenuous objections to "the artistic mind which looks for its subjects into literature instead of life," belie the degree to which her own narrators ground their authority in literature and philosophy and express it in nonrepresentational forms. ${ }^{3}$ When Alexander Main sought permission to compile a collection of these copious passages, Eliot protested that her works could not be reduced

1. See, respectively, Mary Jacobus, "The Question of Language: Men of Maxims and The Mill on the Floss," in Writing and Sexual Difference, ed. Elizabeth Abel (Chicago: University of Chicago Press, 1982), 44; Sandra Gilbert and Susan Gubar, The Madwoman in the Attic: The Woman Writer and the Nineteenth-Century Literary Imagination (New Haven: Yale University Press, 1979), 523; and Carol Gilligan, In a Different Voice: Psychological Theory and Women's Development (Cambridge: Harvard University Press, 1982), 69, 130-31, 143-44, 148-49.

2. George Eliot, The Mill on the Floss (New York: New American Library, 1965), book 7, chap. 2, 521 . All further references will appear in the text.

3. Letter to Mary Sibree (1843), cited in Jennifer Uglow, George Eliot (London: Virago, $1987), 39$. 
to an "assemblage of extracts": "I have always exercised a severe watch against anything that could be called preaching," and "never allowed myself, in dissertation or in dialogue [anything] which is not part of the structure of my books." "Unless I am condemned by my own principles," she concluded, "my books are not properly separable into 'direct' or 'indirect' teaching." to create The Wise, Witty, and Tender Sayings of George Eliot (1871) and apparently authorized a Wit and Wisdom of George Eliot that was published in 1873 (and updated in 1876 ) consisting precisely of extracted, nonnarrative elements of text. The contradiction is clear even in the passages with which I opened, since four of them are extractable "direct teaching" from the very novels that supposedly reject such practices.

If Eliot is saying that neither men nor maxims can be trusted, then, she says so in a syntax of authority that appropriates the very forms she is questioning, just as she authorizes and profits from the "assemblages of extracts" that confirm "George Eliot" as major literary capital. Although Eliot may not be "condemned by [her] own principles," her narrators appropriate the structures and strategies of the "men of maxims" as, I believe, a way out of separate but intersecting dilemmas of gender and narrative voice. I will argue that in Eliot's novels the impulse to "maximize," while complicated by a semantics of ambiguity, constitutes both a vexing dilemma and a major factor in narrative design. Postmodern critics who want to emphasize Eliot's deconstruction of authoritative discourse, and feminist critics who value women writers precisely for their rejection of authority as "masculine," seem to me to be overlooking the degree to which the rhetoric of Eliot's fiction arrogates authority in a project designed precisely to construct a narrative hegemony. Such a project is consistent with the historical situation in which Eliot wrote, and in which the place of the novel in public culture was dependent on specific forms of authorial voice.

Narrative authority gets worked out in Eliot's novels in two distinctly different formations that correspond to early and late periods of her career. I will speculate that these shifts in narrative practice, which include changes in the narrators' status, in their modes of contact with narratees, and especially in their strategies for repre- 
senting narrative stance, stem from the convergence around 1860 of three factors: an instability in the project of realist fiction that Adam Bede had already begun to recognize; the professionalization of the novel in a way that meant the (re)masculinization of its authority; and the public revelation that "George Eliot" was not a "University man" as "all the Oxford and Cambridge gents" may have imagined, but "only a poor woman" living in $\sin .^{5}$ These are the primary factors, I believe, that turn Eliot from "intrusive" narrators who temper the authority they appropriate, to remote narrators who appropriate the authority they seem to be tempering. While the crisis of Northanger Abbey produced in Austen's work a narrative reticence, Eliot's narrative crisis leads to an extraordinary appropriation of a cultural intertext.

Speculating about the novels Jane Austen would have written had she lived beyond 1817 , Virginia Woolf suggests that Austen was beginning to discover a "larger" world that explored "not only what [people] are, but what life is." Woolf's hindsight points less, I think, to potential changes in Austen than to actual changes in the tradition that followed her. The kind of novel emerging in Europe during the 1830 and 1840 , epitomized in the ambition of Balzac's Comédie humaine, embraces a new representational imperative: not simply to delineate "human nature" in its "varieties," as Austen described the novel's project, but to produce, in Pierre Macherey's words, a "book which shall be like a world." Such an imperative requires the text to construct a "dispersion" or "diversity" through a proliferation of detail and a "broken plot" with "several abruptly discontinuous foregrounds," all signified in the trope-adopted by Eliot, Stendhal, and other nineteenth-century realists - of the novel as a mirror reflecting whatever passes by. ${ }^{7}$

While such a program would seem to constitute the narrator as mere transcriber, leaving no place for the pedagogic imperative by which the previous century had justified literature, in realist narrative

5. Letter from George Henry Lewes to Barbara Bodichon of 5 May 1859 , in ibid., vol. 3, 65; Letter from George Eliot to Georgianna Burne-Jones, cited in Deirdre David, Intellectual Women and Victorian Patriarchy (Ithaca: Cornell University Press, 1987), 168.

6. Virginia Woolf, "Jane Austen," in The Common Reader (New York: Harcourt Brace, 1925), $148-49$.

7. Pierre Macherey, A Theory of Literary Production, trans. Geoffrey Wall (London: Routledge, 1978), 268, 271. The notion that the novel produces a "world" has grounded novel theory at least since Lukács. On the novel as "mirror," see the epigraph to chap. 13 of Stendhal's The Red and the Black, and chap. 17 of Adam Bede. 
the moral project actually takes on new urgency. Since the novel is to produce a diversity, its coherence must come from the narrator, who mediates this complexity not only aesthetically but ideologically. These demands, however, generate another paradox: as Macherey explains, the novel is expected to show "things as they are," but also to show things as they should and should not be. As Eliot formulates them in chapter 17 of Adam Bede, such imperatives compel the narrator on the one hand to "tell you, as precisely as I can, what that reflection is, as if I were in the witness-box narrating my experience on oath," and on the other to partake "in the secret of deep human sympathy" that transforms the "common" and "coarse" to the cherished. ${ }^{8}$ Such a contradiction between representation and evaluation creates an acute instability in narrative form: the illusion of what is (mimesis) interferes with the declaration (diegesis) of what ought to be. In this economy an explicit narrative stance provides the readiest mechanism for shaping judgment but also arrests representation and ruptures the mimetic illusion on which the realist novel depends. The representation of "things as they are" implies the narrator's ostensible absence, while the expression of judgment implies the opposite. ${ }^{9}$

One project of the realist novel, therefore, is to accommodate the contradictions between knowing and judging, or representation and ideology, through an unprecedented authorization of the heterodiegetic voice, which must stand against the realist novel's necessary production of "speaking persons" whose discourses threaten to destabilize any ideological hegemony. ${ }^{10}$ Hence the abandonment of eighteenth-century homodiegetic and multivocal narrative forms in favor of the pervasive structure of classic realism: the single, extradiegetic and public voice, sole mediator of the fictional world, who occupies a "higher" discursive plane than the characters, entering into a compact with public narratees who, if they read rightly, are privileged to share the narrator's enlightened place.

It is only a slight exaggeration to suggest that upon this narrator rested the demands and powers of divinity itself, trusted at once to know all and to judge aright, the self-authorizing authority "who does

8. George Eliot, Adam Bede (Harmondsworth, England: Penguin, 1980), 221,224 . Further references will appear in the text.

9. See Gérard Genette, Narrative Discourse: An Essay in Method, trans. Jane Lewin (Ithaca: Cornell University Press, 1980), 166.

10. Mikhail Bakhtin, The Dialogic Imagination, trans. Caryl. Emerson and Michael Holquist (Austin: University of Texas Press, 1981), 332. 
not require verification" and who "verifies all other statements" that "the source and evidence of the truth of the [narrator's] interpretation" is not, as it was a century earlier, (the illusion of) empirical evidence, but (tautologically) the narrative voice itself. ${ }^{12}$ Whether one imagines such a narrator as Balzac's statesmanlike "tutor of men," as Robert Scholes's "benevolently despotic" entrepreneur ruling the textual world "as the laissez-faire capitalists ruled their factories," as J. Hillis Miller's "all-embracing consciousness which surrounds the minds of the characters," as Lennard Davis's imperious master who demands the reader's submission, or as what we might today understand as the very spirit of imperialist Europe fulfilling its mission to colonize subjects with an unshakeable confidence in its moral and intellectual superiority, narrative voice in the mid-nineteenth-century realist novel operates on the startling myth that, as Davis bluntly puts it, a person "who spends a good deal of his or her life making up stories" is somehow both an "archivist of knowledge" and a philosophical and moral arbiter of "real life." ${ }^{13}$ Realist "omniscience," then, means far more than a narrator's privileged knowledge of fictional facts.

By the mid-1 85 os, when Eliot began publishing novels, these conflicting textual imperatives were connected to equally conflicting institutional ones as fiction became increasingly prestigious and lucrative. Eliot, with her legendary longing at once for literary, popular, and financial success, ${ }^{14}$ tries to set up a positive relationship between commercialism and artistry when she complains that "silly novels" are written not by the genteel poor but "in elegant boudoirs, with violetcolored ink and a ruby pen" by women irresponsibly "indifferent to publishers' accounts, and inexperienced in every form of poverty

1 1. Stanislaw Eile, "The Novel as an Expression of the Writer's Vision of the World," New Literary History 9 (Autumn 1977): 120.

12. Catherine Belsey, Critical Practice (London: Methuen, 1980), 70-72.

13. See, respectively, Balzac, preface to La Comédie humaine; Robert Scholes, "The Liberal Imagination," New Literary History 4 (1973): 526; J. Hillis Miller, The Form of Victorian Fiction (Notre Dame: University of Notre Dame Press, 1968), 83; and Lennard Davis, Resisting Novels: Ideology and Fiction (London: Methuen, 1987), 142-43. See also Carl D. Malmgren, "Reading Authorial Narration: The Example of The Mill on the Floss," in Poetics Today 7 (1986): 47879 .

14. On Eliot's intellectual aspirations see especially David, Intellectual Women. On Eliot's desires for commercial success see especially Ruby Redinger, George Eliot: The Emergent Self (New York: Knopf, 1975); and Catherine Gallagher, "George Eliot and Daniel Deronda: The Prostitute and the Jewish Question," in Sex, Politics, and Science in the Nineteenth-Century Novel, ed. Ruth Yeazell (Baltimore: Johns Hopkins University Press, 1986), 39-62. 
except poverty of brains." 15 With the superiority of the middle-class "organic intellectual," ${ }^{16}$ Eliot links bad literature with the extremes of both "the old Grub Street coercion of hunger and thirst" and the "gratuitous productions of ladies and gentlemen whose circumstances might be called altogether easy." author as godly father was tarnished by the writer's participation in what was viewed as a prostituting economy. Commercial success also required care in constructing the authorial narrator's relationship to the public narratee, lest the contact between (textual) "author" and (textual) "reader" deter a paying audience.

I want to speculate that one narrative mechanism for "solving" simultaneously both of the contradictions I have been describing-a way, that is, to obscure both the author's economic dependence on her reading public and the formal contradiction between representation and judgment - was to purge from a novel's narrative surface all explicit markers of narrative status, contact, and stance. I refer here, as the "solution" to the problems of both realism and professionalism, to the Flaubertian model of "effacing" overt authoriality and its potential for direct contact between narrator and narratee; this gesture is represented clearly within Madame Bovary (1857) when the "we" who is the text's initial narrator dissolves into an unidentified impersonal voice. Eliminating the overt narrator "resolves" realism's conflicts by conflating representation and ideology and subsuming the commercial enterprise beneath the artistic one, modeling a specular technology (the forerunner of cinematic realism) that manipulates the "mirror" without revealing the hand that holds it. Eliot's narrators never go this far, but neither do the later novels follow Adam Bede in exposing the "mirror" as "doubtless defective" or in making direct, of ten ironic jibes at the foibles of various narratees. Opposition to such "authorial intrusion" becomes "firm" in England as early as $186_{5},{ }^{18}$ and as I will suggest in Chapter 6 , by the next century overt authoriality will cede to selectively focalized, "figural" narration in

15. George Eliot, "Silly Novels by Lady Novelists," in Selected Essays, Poems and Other Writings, ed. A. S. Byatt and Nicholas Warren (London: Penguin, 1990), 142.

16. The term is Antonio Gramsci's. See Selections from the Prison Notebooks (London: Lawrence and Wishart, 1971), 18.

17. George Eliot, "Diseases of Small Authorship" in Impressions of Theophrastus Such, vol. 20 of The Writings of George Eliot (Boston: Houghton Mifflin, 1908), 205.

18. Kenneth Graham, English Criticism of the Novel 1865-19oo (Oxford: Clarendon Press, $1965), 123$. 
which the narrator's text is formally inseparable from the texts of characters.

What I have been describing as a multifaceted rise in the novel's authority in the nineteenth century undermined the authority of women novelists in ways easily obscured by the numbers of women in the literary marketplace. Athough women helped to make the novel a powerful social vehicle in the period from 1847 to 1860 that Nancy Armstrong identifies with the "domestic" authority of such writers as Elizabeth Gaskell, Charlotte Brontë, and Harriet Beecher Stowe, "feminine authority" was becoming a fiction. Gaye Tuchman and Nina Fortin convincingly demonstrate that the professionalization of the novel especially after 1860 tended to squeeze women out of the production of "serious" fiction despite (or because of) their role in making the novel a professional genre. ${ }^{19}$ As Mary Poovey comments, "If the feminization of authorship derived its authority from an idealized representation of women and the domestic sphere, then for a woman to depart from that idealization by engaging in the commercial business of writing was to collapse the boundary between the spheres" as well as "the ideal from which her authority was derived."20

It seems likely that realism's conventions of powerful, public narrative voices authorized to mediate important contemporary questions at a time of particularly rigid separations between "male" and "female" spheres, supported a masculine authorial identity and legitimated the squeezing out of women from the ranks of "serious" novelists. The contradiction between female status and narrative authority is signaled by the widespread use after 1860 of the male pseudonym by women novelists in nineteenth-century England and France, at just the moment when the novel was becoming a serious literary form; such a practice acknowledges that narrative status is authorized diegetically according to the social identity of the (presumed) author rather than, as in early periods, mimetically according to the truth

19. Gaye Tuchman with Nina Fortin, Edging Women Out: Victorian Novelists, Publishers, and Social Change (New Haven: Yale University Press, 1989), 215 . See also "Edging Women Out: Some Suggestions about the Structure of Opportunities and the Victorian Novel," Signs 6 (1980): 308-25. Tuchman and Fortin show that from 1866 to 1887 the "growing prestige of the novel in England" reduced "the opportunities for women to have their work seriously considered and to achieve fame." Terry Lovell makes a similar argument in Consuming Fiction (London: Verso, 1987), 43.

20. Mary Poovey, Uneven Developments: The Ideological Work of Gender in Mid-Victorian England (Chicago: University of Chicago Press, 1988), 125. 
claims made for the narrative itself. Richard Simpson, in an essay of 1863 that attacks Eliot (along with Behn, Staël, Sand, Charlotte Brontë, and others who "misuse their sex"), articulates the fear of women's power as a sexual fear and urges women to restrict themselves to "indirect" strategies: "Women work more by influence than by force, by example than reasoning, by silence than speech: the authoress [Eliot] grasps at direct power through reasoning and speech. Having thus taken up the male position, the male ideal becomes hers, - the ideal of power,- which, interpreted by her feminine heart and intellect, means the supremacy of passion in the affairs of the world." ${ }^{21}$ Such attitudes were likely to constrain the forms through which women might effectively constitute authorial narrative. For example, reviews of Uncle Tom's Cabin, unquestionably the most socially influential novel of the century, criticize the authorial voice for attempting "imperiously and violently to dictate" to readers or for allowing "anti-slavery sentiment" to "obtrude by the author in her own person," 22 but George Sand suggests the sexual double standard at work in these judgments: "For a long time we have striven in France against the prolix explanations of Walter Scott. We have cried out against those of Balzac, but on consideration have perceived that... every stroke of the pencil was needed for the general effect. Let us learn then to appreciate all kinds of treatment, when the effect is good, and when they bear the seal of a master hand.... In matters of art there is but one rule, to paint and to move. And where shall we find creations more complete, types more vivid, situations more touching, more original, than in 'Uncle Tom'?"23 The dilemma I associated in my first chapter with the use of "women's language" is now enacted on the terrain of authorial voice: restrained "lady novelists" are not taken seriously (this is precisely the period when Austen's reputation drops), but powerful female voices are condemned. Eliot's "Silly Novels by Lady Novelists," with its complaint that women without talent receive "journalistic approbation" at "the boiling-pitch," while for women of genius "critical enthusiasm drops to the freezing

21. Richard Simpson, "George Eliot's Novels," in George Eliot: The Critical Heritage, ed. David Carroll (New York: Barnes and Noble, 1971), 241.

22. Anonymous reviews in London Times, 3 September $185^{2}$, and Putnam's Monthly, January 1853 .

23. George Sand, review in La Presse, 17 December 1852, cited in Critical Essays on Harriet Beecher Stowe, ed. Elizabeth Ammons (Boston: G. K. Hall, 1980), 4. Sand does not recognize any racism in Stowe's "vivid" representations. 
point," ${ }^{24}$ both criticizes and perpetuates this growing male hegemony and, functioning as it does as a prelude to her first published fictions, seems to be clearing the space for her own authority.

As Simpson's comment implies and "Silly Novels by Lady Novelists" anticipates, Eliot's literary imperatives crystallized the contradictions both between gender and authority in Victorian England and between representation and judgment in realist narrative. A scholar and essayist before she was a novelist, Eliot brought to her fiction an intellectual agenda that, Tuchman and Fortin would suggest, could at that time only have hindered a woman novelist's career. No realist novel had yet turned the genre to imperatives as pedagogic and intellectual as Eliot's, nor was Victorian culture amenable to a woman's bold appropriation of the philosopher-historian's role, which centuries of Western tradition had deemed the right of privileged-class white men. Together, these transgressions produced criticisms of Eliot's work such as the Westminster Review's complaint that her novels are "elaborately tedious" because they fail to subordinate "clevernesses, or eruditions, or sciences" to the all-important "tale"; Eliot is derided as one of those "inferior writers" who have "to prove that they are excellent story-tellers, or that they know all science, or are 'well up' in art" and who have failed "to subordinate [their] personal interests to the larger interests of [their] art." 25

Eliot's novelistic career also spans the transitional period I have been describing in which the novel is moving from the uneasy earlyrealist coexistence of representation and overt ideology to the laterealist practice of representation "alone." The disclosure, as she was finishing Mill on the Floss, that Eliot was a woman and an unlawful wife converges with the novel's increasing stature and an incipient cultural preference for Flaubertian narrative strategies, to explain the shifts in narrative practice between Eliot's early and late works-shifts marked by the abandonment of an uninvolved eyewitness male narrator, of explicit generalizations, and of direct contact between narrator and narratee in favor of a surprisingly little-noted development of new "extrafictional" structures that constitutes "Eliot" as an ultimate literary authority even as her narrators withdraw from the obviously "intrusive" practices of the early works. In the guise of accommodating

24. Eliot, "Silly Novels by Lady Novelists," 161 .

25. Westminster Review (July 1878), cited in George Eliot and Her Readers: A Selection of Contemporary Reviews, ed. John Holmstrum and Laurence Lerner (New York: Barnes and Noble, 1966$), 176-77$. 
a more restricted narrative authority, in other words, Eliot's later narrators inaugurate even more appropriative practices.

As early as “Mr. Gilfil's Love Story," Eliot's narrators are producing long passages of explicit comment linked to the narrative through various formal strategies: beginning with generalization and then moving to the perspective of a character (chap. 5); narrating an event, pausing to comment on its general significance, and returning to the event (chap. 6); embedding a generalization in the middle of a paragraph (chap. 16). ${ }^{26}$ As a compensatory gesture, however, these early texts adopt several strategies that appear to render this authority contingent, personal-and male. I refer to three particular practices: direct contact with the narratee; quasi-dramatized narrators, and the use of qualifying or perspectivizing language for expressing narrative stance. Eliot invented none of these strategies, and each was practiced by at least one contemporary woman novelist whom Eliot admired: Sand, Gaskell, Brontë, Stowe.

Robyn Warhol has already written of the "engaging" narrator who directly addresses a public readership, discusses the characters as if they are historical individuals, and guides the narratee's sympathies. ${ }^{27}$ This "earnest" address, practiced by women such as Gaskell and Stowe, with whom Eliot corresponded, was, used, says Warhol, "to bridge the gap between strictly literary utterances and serious statements"28 by exhorting the narratee to a moral or political stance. Warhol suggests that the "engaging narrator" has a historical specificity, reflecting perhaps “certain nineteenth-century women's impulses to speak-if not from a pulpit then from a text-directly, personally, and influentially in the only public forum open to them." 29 These narrators attempt, in other words, to balance "masculine" assertiveness with "feminine" concern for audience.

26. See George Eliot, Scenes of Clerical Life (Harmondsworth, England: Penguin, 1973). Citations will appear in the text.

27. Robyn R. Warhol, "Toward a Theory of the Engaging Narrator: Earnest Interventions in Gaskell, Stowe, and Eliot," in PMLA 101 (October 1986): 811-18.

28. Warhol, Gendered Interventions: Narrative Discourse in the Victorian Novel (New Brunswick: Rutgers University Press, 1989), 169. Warhol believes "engaging address to the reader is a sign of these women's conceptions of the purpose of art; as such, it signifies a gendered gesture" $(169-70)$. I would say that any number of male writers, including Dickens and Balzac, shared this referential purpose although they engage much less frequently in direct address. Frederick Douglass's Narrative, for example, does not directly address its narratee while Harriet Jacobs's Incidents in the Life of a Slave Girl does, yet both works share an urgent ref erential earnestness. If "engaging" narration is gendered, it is gendered as a question of authority rather than one of pedagogical intent.

29. Warhol, "Engaging Narrator," 817 . 
The narrative "engagements" in Eliot's first two novels, which are more elaborate and more frequent than in Gaskell's or even Stowe's, support the novels' generalizing practices by establishing a similar sense of connection with the narratee. Because neither her life nor her philosophy was conventionally Christian, Eliot had even more reason than the clergymen's wives Gaskell and Stowe to seek narrative "engagement": even her publisher worried that she took "the harsher Thackerayan view of human nature," and urged her "to soften your picture as much as you can." ${ }^{30}$ But Eliot does not construct the domesticated female narrators chosen by Gaskell and Stowe; rather, the model for her early narrators came quite probably from George Sand. Openly committed, like Eliot, to the practice of serious literature and to the intellectual and moral questions of her day, and living and writing outside the bounds of propriety, Sand was like Eliot unable to call upon the "feminine" authority, however limited, that Gaskell and Stowe could exploit. Moreover, Aurore Dupin Dudevant and Marian Evans Lewes created their professional identities upon fictions of biography, exploiting the male pseudonym and creating masculine narrative voices to support this fictive identity. While Sand's novels (over seventy in number) adopt a range of narrative practices, one of her most typical narrators is a male figure whose presence is manifestly gratuitous-a narrator who could easily have been an ordinary heterodiegetic voice of indeterminate sex but who turns up, sometimes at the very end of the novel (in Indiana), or sometimes at the beginning (in Mauprat), as an explicitly male eyewitness or author-surrogatethe kind of narrator created as female in the novels of Aphra Behn.

Eliot adapts for her earliest fictions this quasi-dramatized narrator modeled by Sand. Because such a narrator is represented as a kind of character-an uninvolved eyewitness recalling his past-there is a mimetic legitimation for his presence in the text and thus a mimetic basis for his status as knower and judge; such a narrator's ideological comments, rather than detracting from the mimesis, might well enhance the illusion of a true history. This use of the male narrator is thus not only an authorizing strategy but a tempering one: Sand and Eliot bring their narrators down to human scale, novel becomes story, the personal context of speaking and listening is implicitly engaged, and narrator and reader are established as a community. At the same

3o. Letter from John Blackwood to George Eliot of 8 June 1857 , in George Eliot: The Critical Heritage, 57. 
time, the sex of this mediating narrator allows the text to partake of the professional authority that, in mid-nineteenth-century France even more than in England, was resoundingly masculine.

In the first three novels, Eliot's narrators also contextualize the grounds of their authority by generalizing in a language of perspectival contingency. Many of the "maxims" in these novels carry qualifying tags: "Yet surely, surely" (Clerical Life, 322); "if I have read religious history aright" (Adam Bede, 81); "I believe" (Adam Bede, 198); "I cannot say" (Adam Bede, 241); "I have of ten wondered" (Mill on the Floss, 19); "I have understood from persons versed in history" (Mill on the Floss, 267); "In natural science, I have understood" (Mill on the Floss, 287); "I suppose this is the reason" (Mill on the Floss, 3o6). Through such practices the narrator's totalizing potential is tempered by strategies that Robin Lakoff has associated with "women's language" or "language of the powerless," but which Julia Penelope Stanley identifies more positively as the recognition of contingency and perspectivity. ${ }^{31}$ By representing understanding as conditional, such tags qualify not only the generalizations but the authority of the voice that utters them.

All of these early strategies, whether deliberate or not, temper a woman's usurpation of public authority; the strategies of the later novels, in contrast, insist on that same authority without acknowledging or engaging its terms even at the risk of offending audiences to whose opinions Eliot was keenly and of ten debilitatingly sensitive. For readers of Clerical Life and Adam Bede were engaging a masculine voice they did not take to be fictional; Eliot's gender had not yet been revealed even to her publisher, and her friends may well have been right to believe that Adam Bede "could not have succeeded if it had been known as hers; every newspaper critic would have written against $i t . "{ }^{32}$ Eliot was in fact extremely successful in creating her fiction of authorship; letters to her and to Lewes suggest that many believed the author to be a clergyman-which distanced the narrative voice even further from the freethinker and "adulteress" Marian Evans, who had translated Ludwig Feuerbach and David Friedrich Strauss and written "atheism" in the pages of the Westminster Review. The choice of pseudonym had been calculated to serve just this end; as

31. Julia Stanley, "The Stylistics of Belief," in Teaching about Doublespeak, ed. D. J. Dietrich (Urbana: National Council of Teachers of English, 1976).

32. Letter from Barbara Bodichon to George Eliot of 28 June 1859 , in The Letters of George Eliot, vol. 3, 103 . 
Lewes wrote to Barbara Bodichon, "the object of anonymity was to get the book judged on its own merits, and not prejudged as the work of a woman, or of a particular woman. It is quite clear that people would have sniffed at it if they had known the writer to be a woman but they can't now unsay their admiration."33

As the remarkable rereviewing of Adam Bede by Athenaeum proved ${ }^{34}$ people could in fact "unsay their admiration." But the overtly authorial narrators of the early novels had provoked resistance even before Eliot's identity was revealed. A reviewer of Clerical Life, for instance, objected to the number of sentences that "finished in an epigram or aphorism" and commented that "casual phrases like these betray a mind of philosophic culture, but they mar the simplicity of the style." ${ }^{35}$ A reviewer of Adam Bede found similar fault with the way in which "the author intrudes himself in the book.... He makes a great deal too much of a very slight novelty of opinion at which he himself has arrived, and he puts the merit of holding this opinion on much too grand a footing." ${ }^{36}$ This may be one reason why, as Warhol notes, Eliot (like Stowe and Gaskell) "eschewed engaging narrative in later works." ${ }^{37}$ But in Eliot's case there was almost surely at work the public disclosure that put her in a more vulnerable relationship with the reading public on whom her fame and fortune relied-especially after The Mill on the Floss, which generated more negative criticism than the earlier novels for representing a rebellious and passionate heroine who, it was said, carried the reader's sympathies into moral "chaos." This may explain Eliot's turn after Mill on the Floss to the pastoral Silas Marner, by far the thinnest novel in generalizing comments and one of her most popular works among Victorians, and then to the distanced setting of fifteenth-century Italy for Romola, which forced her to abandon her dramatized reminiscing narrator and allowed her to write her most intellectual (and partly for that reason her least popular) book. ${ }^{38}$

33. George Lewes, in ibid., 106 (3o June 1859).

34. See Elaine Showalter, A Literature of Their Own: British Women Novelists from Brontë to Lessing (Princeton: Princeton University Press, 1978), 95.

35. Unsigned review in Saturday Review (29 May 1858), in George Eliot: The Critical Heritage, $69-70$.

36 . Ibid., 76 .

37. Warhol, "Engaging Narrator," 816.

38. One contemporary review, for example, lamented the "tax on our patience" generated by the novel's "long accounts," "translations of sermons," and "extracts from chronicles" (Saturday Review, 25 July 1863), in George Eliot and Her Readers, 65. 
When Eliot returns to nineteenth-century English settings in Felix Holt, Middlemarch, and Daniel Deronda, she has abandoned the dramatized narrators and most of the narrative engagement of the early novels in favor of more distanced strategies for expressing narrative stance. Perhaps because the disclosure of Eliot's identity ruptured the rapport between narrator and narratee that had been generated through the fiction of maleness, in the later novels Eliot's narrators assert authority without engaging the reader in its construction or acknowledging dependence on an audience. That this new posture came to be lauded as a move toward propriety-a propriety perhaps sexual as well as textual-is suggested in the language, strikingly like that of the Victorian reviewers, with which Walter Allen later describes the change:

\begin{abstract}
After The Mill on the Floss [Eliot's] digressions were much more curbed, her asides much less flagrant and her comment much more closely woven into the texture of her narrative. After Adam Bede there is nothing quite so obtrusive as [chap. 17], and when one turns from The Mill on the Floss to Felix Holt, written several years later, one is conscious immediately of a sharp increase in dramatisation; the action is allowed much more to speak for itself. W. J. Harvey... gives the ratio of omniscient intrusions in terms of pages as, in Adam Bede 1:10, in Mill on the Floss 1:14, in Middlemarch, 1:33. Once she has learned how to control them they are, of course, much more acceptable. ${ }^{39}$
\end{abstract}

But even the reduction Allen claims for Middlemarch is a difference less in the degree of authoriality than in the forms it takes, and Eliot was certainly criticized for didacticism in her last two novels. ${ }^{40}$ What

39. Walter Allen, George Eliot (London: Weidenfeld and Nicolson, 1965), 89 (my italics). Neither Allen nor Harvey explains what counts for an "omniscient intrusion."

40. For example, the Spectator of 1 June 1872 grudgingly admitted that "we all grumble ... that there is too much parade of scientific and especially physiological knowledge in it, that there are turns of phrases which are even pedantic, and that occasionally the bitterness of the commentary on life is almost cynical; but we all read it, and all feel that there is nothing to compare with it appearing at the present moment in the way of English literature." The reviewer attributes most of the "unhappiness" in Middlemarch to "the authoress's own comments on the universe and its structure" ("The Melancholy of Middlemarch," in George Eliot: The Critical Heritage, 297). Daniel Deronda received much more negative press, including Saintsbury's regret that "the characters are incessantly pushed back in order that the author may talk about them and about everything in heaven and earth while the action stands still." In the Academy (9 September 1876); reprinted in George Eliot: The Critical Heritage, 374. One should not discount the discomfort readers may have experienced over the Jewish-and proJewish - content of Daniel Deronda; one review complains that the reader never or rarely "feels at home" in the novel: "the author is ever driving at something foreign to his habits 
does disappear is direct engagement, and despite exceptional passages like the beginning of chapter 15 of Middlemarch, which I cite in my epigraph to this chapter, the authorial generalizations in the last two novels are usually brief embeddings within seemingly narrative paragraphs.

Yet these narrators have also found new ways to consolidate their authority. Maxims that in earlier novels would surely have been qualified in some way are simply presented as if they were true; now narrative comments are rarely contextualized. Julia Penelope Stanley describes this phenomenon in which the perceiving and evaluating "I" is removed from the discourse and replaced by passive adjectives, the universal "we," or an enunciation whose source is suppressed. Stanley comments: "The deletion of the experiencer imparts to the statement an impersonal tone of authority, giving a personal observation the weight of 'universal consensus.' By deleting the experiencer, the author conveys the impression that the judgment or perception is one that everyone agrees with, thus claiming universal consensus for individual opinions." ${ }^{11}$ The erasure of the enunciator's perspectivity, and the consequent absence of any acknowledgment that an utterance is contingent or contextual, is a phenomenon that Stanley associates with "masculine" language and that I would link to the language of any ideologically dominant group. In Middlemarch and Daniel Deronda, generalizations are either entirely uncontextualized or connected with a totalizing "we," as in "We do not expect people to be deeply moved by what is not unusual, ${ }^{, 42}$ a subtle structure that appears to involve the narratee in the enunciation but actually speaks on the narratee's behalf. ${ }^{43}$ This is not the explicitly male narrator of the early work; it is the unmarked Male of Authority itself, all the more powerful for being invisible and impersonal rather than particularized and sexualized. ${ }^{44}$ Eliot's narrators may be more remote in these later novels, then,

of thought." "Home" is Christian England, and a woman's job is to make "home." Unsigned review in Saturday Review (16 September 1876); cited in George Eliot: The Critical Heritage, 377 .

41. Stanley, "The Stylistics of Belief," 182.

42. George Eliot, Middlemarch (New York: New American Library, 1964), chap. 20, 191. Further references will appear in the text.

43. Both Barbara Hardy and J. Hillis Miller see the narrator of these later novels as a collective or communal voice because of the "inclusive use of 'we.' "In Barbara Hardy, The Novels of George Eliot: A Study in Form (London: Athlone: 1963), 163; and J. Hillis Miller, The Form of Victorian Fiction. But if one examines these passages, the "we" is not the subject of enunciation but only the subject of the the enoncé. In other words, the implicit, unnamed subject remains "I," and this "I" is telling "us" what "we" think and feel.

44. See Davis, Resisting Novels, 138. 
but they are not ceding voice; they have become "imperious, if sympathetic" presences. $^{45}$

Indeed, Eliot devises for the late novels beginning with Felix Holt whole new maximizing structures that separate authorial comment from the body of the text-the "extrafictional" structures of introductions, epigraphs, and epilogues. These structures formally distinguish mimesis from maxim, so that authoriality cannot be said to "intrude" upon the representation of "real life." Romola, for example, opens with a long "Proem," the term itself suggesting the erudition that the novel will carry and distinguishing the introduction from ordinary (women's?) prefaces. Felix Holt begins with an "Introduction," and Middlemarch with a "Prelude"; three of the last four novels end with a "Finale" or epilogue. Once again, a contrast is valuable: although she wrote novels that engaged political and social themes as important as Eliot's, “Mrs. Gaskell” declared herself much too modest to address her audience publicly in no-longer-requisite prefaces. ${ }^{46}$

The most pervasive and, I believe, ultimately the most audacious of Eliot's narrative strategies is one that seems to have been the least remarked upon, and that may by why it served Eliot so well: every chapter in the last three novels-and, but for her publisher's objections, Romola as well-is introduced with an epigraph ("motto," to Eliot), a vehicle for direct generalizing commentary in an authorized voice. ${ }^{47}$ In adopting epigraphs Eliot is again appropriating and transforming a practice far more common among nineteenth-century women than men. Although Scott, who used chapter mottos in the Waverley novels, is taken to be the inspiration for Eliot's epigraphy, ${ }^{48}$ using epigraphs became a prominent and earnest practice primarily among women novelists in England and America; they appear, for instance, in Susanna Rowson's Charlotte (1791), Mary Brunton's Discipline (1815), Susan Ferrier's Marriage (1818), Susan Warner's The

45. David, Intellectual Women, $16_{5}$.

46. On Gaskell's pretense of ignorance, see Lovell, Consuming Fiction, 87-88. To my knowledge, the only woman of the mid-nineteenth century who routinely wrote prefaces that engaged current literary and social questions was George Sand, whose prefaces were a model for Henry James and probably for Eliot as well.

47. At least one critic did comment specifically on the "mottos": Sidney Colvin, in the Fortnightly Review (1 November 1876), complains that "moral and philosophical problems do not clothe themselves" in Eliot's novels "in appropriate artistic forms. We have passages of first-rate art side by side with passages of philosophy; and sometimes the philosophy comes where we want the art" (in George Eliot and Her Readers, 172, 176).

48. Waverley itself $(1814)$ has no epigraphs, while Mary Brunton's Discipline, published in Scotland in the same year as Guy Mannering (1815), does. 
Wide, Wide World (1851), Elizabeth Gaskell's North and South (1855), Harriet Wilson's Our Nig (1859), and sporadically in Uncle Tom's Cabin. Women writers in the nineteenth century might have had a particular predilection for the epigraph as a means for suggesting the scope of their knowledge, giving the novel an intellectual and moral weight, and lending external authority to their textual stance.

Eliot, however, takes epigraphy to new, self-authorizing extremes. While other women draw their epigraphs almost exclusively from English and American sources, Eliot quotes Heine, Dante, Montaigne, Molière, Musset-in the original. While other women use primarily brief verses, Eliot of ten chooses substantial prose passages. While other women frequently quote scripture, of 225 epigraphs in Eliot's last three novels, only three are biblical. While other women frequently cite women as well as men, only one of Eliot's mottos can be attributed to another woman (Elizabeth Browning). ${ }^{49}$ Seventy-five of Eliot's sources are used only once or twice; while Susan Warner reveals her knowledge of Shakespeare, Milton, Cowper, and Burns by quoting them frequently, Eliot's epigraphs suggest an inexhaustible and esoteric store of references. In short, while other women create an evocative, English-language, and sexually mixed intertext through their epigraphs, Eliot's epigraphy constitutes a pan-European canon of learned men that, like Sarah Fielding, she appears to master. If epigraphs reinforce the literary project over the commercial one, and if Catherine Gallagher is right to suggest that the dominant image against which Victorian women writers struggled was not the father but the whore, Eliot's epigraphy uses the literary fathers to cover "the guilt of usurious and whorish commercial appropriation" and helps create the "artificial construction of a superseding moral economy."

But Eliot's epigraphy goes further still: it transforms the narrator herself into a literary "father" by reauthorizing her voice as if it belonged to someone else. If one were to construct an Eliot who first "saw herself not as a creator of literature but only as an editor and translator whose skills in expression were to be subordinate to the meaning of another's words," ${ }^{, 51}$ one might be tempted to see the epi-

49. I have drawn most of my information about Eliot's epigraphs from J. R. Tye, "George Eliot's Unascribed Mottoes," in Nineteenth Century Fiction 22 (1967): 235-49; and David Leon Higdon, "George Eliot and the Art of the Epigraph," Nineteenth Century Fiction 25 (1970): 127-51. Especially valuable is Higdon's appendix, which charts the sources and distribution of epigraphs in the three novels.

50. Catherine Gallagher, "George Eliot and Daniel Deronda," 47.

51. Gilbert and Gubar, The Madwoman in the Attic, $45^{\circ}$. 
graphs as a continuation of feminine servitude. But in fact the major contributor to Eliot's mottos, the literary voice that dominates the tradition evoked through these collective passages, is Eliot's own. Of the 225 epigraphs, a full ninety-six, three times the number from Shakespeare and 45 percent of the whole, were probably authored by Eliot. These epigraphs employ a variety of genres from poetry to drama to philosophical prose, as if Eliot's writings could alone constitute an entire literature. They appear without attribution as if their source were obvious, and they of ten masquerade as sections of longer works, excerpts from apparently nonexistent plays or poems. While Felix Holt carries the largest proportion of epigraphs authored by Eliot herself, these are generally brief and in verse, while Daniel Deronda is given to long prose paragraphs much like the extended generalizations that of ten begin chapters in "Janet's Repentence" and The Mill on the Floss and seem to have caused so much offense.

Together, then, Eliot's epigraphs create a supertext and intertext in which the extrafictional "George Eliot" stands among male voices as the dominant though unidentified voice. It is significant, I think, that while the authorial acts of the early novels call considerable attention to themselves, these appropriative and more distanced actions are undertaken entirely without acknowledgment. In what we might read simultaneously as an elaborate appropriation and secret joke, George Eliot makes herself her own most quoted sage. Here, in the guise of nonfiction, is perhaps the ultimate fiction of authority. To be sure, Eliot of ten uses these structures-as my own epigraphs to this chapter already suggest - to problematize the kinds of simple and unqualified judgment she associates with the "men of maxims," just as she had used direct engagement in Adam Bede to plead for human sympathy. Eliot's epigraphy thus mediates the tension in her work between a semantics of indeterminacy and a syntax of authority. Critical efforts to erase the tension between these, such as Gilbert and Gubar's suggestion that Eliot creates her own mottos in order to "ridicul[e] the convention of citing authorities," denials of the extent to which, as seems consistent with her historical moment, Eliot sought that authority herself.

There is in fact a particular sleight of hand in Eliot's epigraphy that is absent from other mechanisms that embed textual stance. As Bakhtin suggests, epigraphy works dialogically: it constructs an abstract 
discourse in tension with the chapter's dramatized events; it creates a dialogue between two voices-epigrapher's and narrator's-presumably of different agency. In some four-tenths of Eliot's epigraphs, however, these voices are the "same" voice. Lennard Davis reminds us, of course, that all novelistic "dialogue" - the engagement of textual voice with textual voice-is only a fiction of dialogue, for "everything that comes from the author is autocratically determined," and "the fact that the novel substitutes a simulacrum of conversation does not mean that the truly dialogic is being represented." ${ }^{53}$ If Davis's assumption of a monologic authorial subjectivity can be mitigated by an understanding of the dialogic as internal, then the impasse of single- authored "dialogue" becomes less formidable. Nonetheless, in placing the discourse of "George Eliot" in the (superior) textual position reserved for other voices, Eliot actually creates the discourse that validates her own.

Eliot's professed dislike of quotations, abstractions, and "maxims" stands, therefore, in unresolved tension with the pervasive system of generalization in her work and especially with her practices of epigraphy. It is possible that the more Eliot's narrators use maxims, quotations, and authoritative structures that appropriate the cultural authority of men, the more these same narrators protest against such maxims, so that the content of the generalizations of ten recognizes the contingencies of authority and pluralities of meaning that the form seems to deny. This insistence on a syntax of self-authorization is one sign of what Deirdre David suggests is Eliot's necessary collaboration in her own "iconised" status. ${ }^{54}$ If Eliot seems to question everything, if her commentaries are rewardingly complex, still her narrators assert their right to do the questioning: questioning does not necessarily challenge the authority of the questioner.

It seems, rather, that this questioning of authority that characterizes Eliot's later novels is critical to that authority's very maintenance, much as Austen's disavowals of omniscience sustain her appropriation of authorial stance. Speaking of Middlemarch, D. A. Miller suggests in The Novel and the Police that "by now the gesture of disowning power should seem to define the basic move of a familiar power play, in which the name of power is given over to one agency in order that the function of power may be less visibly retained by another. Im-

53. Davis, Resisting Novels, 178.

54. David, Intellectual Women, 168. 
potent to intervene in the 'facts,' the narration nevertheless controls the discursive framework in which they are perceived as such." Such novels, Miller argues, are "monologic" in the Bakhtinian sense: they are only "sham" struggles. But, as Miller continues, "to speak of sham struggles is also to imply the necessity for shamming them. The master-voice ... continually needs to confirm its authority ..." ${ }^{55}$ Eliot's epigraphs, imperiously heading each chapter as a first Word, relentlessly masculine in the tradition they canonize, crown a career in which the role of women as predecessors and resources, like the gender of Marian Evans, is erased from the surface of the text.

If Austen's authorial narrators are constructed in sexual difference and assert a gynocentric authority, then Eliot's construct themselves in terms of sexual equality. These tendencies toward "difference" and "equality"- those two terms that modern feminists understand as an entrapping false duality-are not merely personal preferences but play themselves out within the gendered dynamics of fiction writing at what I hope I have demonstrated are two very different moments in literary history. If Eliot's authoriality writes the woman as moralist, poet, and intellectual into literary history, only a reader's "extratextual" knowledge of Eliot's gender rather than any explicit textual sign makes this a feminization of authority. If Austen constructs a voice double with demurral, Eliot's authority rests on what may be the most double voice of all-the voice of a woman writing in the name and company of men. ${ }^{56}$ Neither writer yet maps the space where equality, whether narrative or political, can rest on the affirmation of difference. ${ }^{57}$

55. D. A. Miller, The Novel and the Police (Berkeley: University of California Press, 1988), 25 .

56. Like Austen, Eliot used both indefinite free indirect discourse and the direct discourse of characters for some of her boldest generalizing statements. Is it only Gwendolen Harleth, or also the authorial narrator, who thinks that "to become a wife and wear all the domestic fetters of that condition, was on the whole a vexatious necessity" (Daniel Deronda, 4.68)? Certainly it is to Gwendolen and to the princess that Daniel Deronda gives its most "feminist" thoughts-for example, the princess's insistence that she "had a right to be an artist," "something more than a mere daughter and mother" (53.728).

57. On difference and equality see Joan W. Scott, "Deconstructing Equality-versusDifference: Or, the Uses of Poststructuralist Theory for Feminism," Feminist Studies 14 (1988): 33-50. 